\title{
REEXAMINING PROBLEMS AND MANAGEMENT STRATEGIES FOR FIGHTING TERRORISM IN INDONESIA
}

\author{
Hafifuddin \\ Institut Agama Islam Negeri Lhokseumawe \\ Jl. Medan-Banda Aceh Km. 275 No.1, Lhokseumawe \\ e-mail: hafifuddin@iainlhokseumawe.ac.id
}

\begin{abstract}
Terrorism has been one of the problems that is still an actual issue in Indonesia. Studies on this issue have caught the attention of researchers. This study will examine the roots of the emergence of terrorism and strategies for dealing with it in Indonesia. By applying qualitative research methods, this article implies that the emergence of terrorism is based on the problems of ethnic egoism, poverty, non-democratic systems and discrimination. To deal with terrorism in Indonesia, this study proposes a solution where terrorism must be handled through strengthening the role of the government, ulama or the learned Muslim scholars and academia of universities. These three parties must synergize maximally to prevent the emergence and movement of terrorism in Indonesia. In addition, the government needs to strengthen national defense institutions, minimize social disparities, respect human rights and create laws that do not conflict with the social conditions of society, and it is at this juncture that study contributes to the handling of terrorism in Indonesia.
\end{abstract}

\begin{abstract}
Abstrak: Terorisme merupakan persoalan yang masih menjadi isu aktual di Indonesia. Kajian mengenai masalah ini telah menyita perhatian para peneliti. Studi ini akan mengkaji akar kemunculan terorisme dan strategi penanganannya di Indonesia. Dengan menerapkan metode penelitian kualitatif, artikel ini mengajukan temuan bahwa kemunculan terorisme didasari oleh persoalan egoisme kesukuan, kemiskinan, sistem non-demokrasi dan diskriminasi. Untuk menangani terorisme di Indonesia, studi ini mengajukan solusi dimana terorisme harus ditangani lewat penguatan peran pemerintah, ulama dan perguruan tinggi. Ketiga pihak ini harus bersinergi secara maksimal untuk mencegah kemunculan dan pergerakan terorisme di Indonesia. Pemerintah perlu memperkuat lembaga pertahanan nasional, meminimalisir kesenjangan sosial, menghargai hak asasi manusia dan menciptakan undangundang yang tidak bertentangan dengan kondisi sosial masyarakat. Studi ini memberikan kontribusi bagi penanganan terorisme di Indonesia.
\end{abstract}

Keywords: terrorism, Islam, Indonesia, government, ulama 


\section{Introduction}

In regards to acts of terrorism in Indonesia, within 2000-2009 there were 22 recorded bombings, both on a small and large scale. The terrorists blew up the JW Marriott Hotel and the Ritz-Carlton Hotel in Mega Kuningan on Friday morning, July 17, 2009 with the number of victims killed 9 people and injured 55 people. Acts of terrorism in Indonesia started with a bomb explosion that occurred at the Cikini College complex in an attempt to assassinate the First President of the Republic of Indonesia, Ir. Soekarno, in 1962 and continued in the following years until August 2001, namely the Blasting Plaza Atrium, Senen, Jakarta and injured six people. All the bombings in Indonesia from 1962 to August 2001 only became an internal issue country. However, since the World Trade Center (WTC) events in New York, United States on September 11, 2001, which claimed 3,000 victims became a new chapter of the terrorism issue, terrorism eventually became a global issue.

The September 11 incident affected all countries' political policies globally, so it became the starting point for the perception of fighting terrorism as an international enemy. The massacres have united the world against international terrorism. Various attempts have been carried out, even after the 1st Bali Bombing, the Indonesian government established a statutory provision called "Law of the Republic of Indonesia Number 15 2003 concerning Stipulation of Substitute Government Regulations Law Number 1 Year 2002 concerning the eradication of criminal acts of terrorism into law." Moreover, RI Government form a unity specifically called the Special Detachment 88 or Densus 88 . This Special Detachment 88 is a special unit of the Indonesian National Police for combating terrorists in Indonesia. These Special Forces with red vets are specially trained to handle all terror threats, including bomb terror. Several members are also members of the Gegana team. Based on this experience, the Unitary State of the Republic of Indonesia must learn from various events. The events that have occurred must be a lesson for the government, law enforcement, national security forces, scholars, and the whole world community.

Terrors carried out by terrorist groups are necessary reflected so that handling can be done with various strategic approaches both as a group and individually. Public perceptions are quite diverse in addressing and responding to terrorism, anarchism, and radicalism in Indonesia. A massive society is a group of less responsive people to the development of up-to-date issues date. Part of it gives a serious response to tackling and fighting because it can kill people who are not guilty. While partly big response to this is a structured crime by an organization that is mobilized by a radical understanding and tends to understand the context and the wrong text, causing radical, terrorist, and anarchist understanding in every act. Radical understanding causes actions that deviate from religious and state beliefs. There is no religious belief in the text that explains and justifies committing violence until culminating murder, even though sometimes it has gone out of the established norms. Religion teaches peace between believers especially towards 
those who are religious same belief. Likewise, state regulations, the Republic of Indonesia's governing law strictly prohibits and combats attitudes and understandings of radicalism, terrorists and anarchists, both individuals and certain groups that develop in Indonesia. This understanding needs to be fought and eliminated in this country beloved Indonesia, wherever and whenever it is. Understand this can snarled, destroying unity, worrying about, destroying peace, disturbing the harmony of the religious community and the state. Terror and radical attitudes in the last few decades have claimed many innocent victims. Event after event becomes very heartbreaking because it leaves negative perceptions of groups acting on behalf of religion. View most of the world community, Islam is an easy target to blame. Indicator of this is deduced from the attributes and symbol from the perpetrator. It's really very unfair just because of the wrong understanding and just a bunch of fanatic Islam does action terror and radicalism and then blamed on the adherents of Islam overall.

This article tries to give discourse on strategic approaches in handling radicalism and terrorism in various fields, hoping that at least it can reduce the action of terrors that happened in various parts of the world, particularly in Indonesia. The formulation of the problem to be answered is how the root cause of the emergence and development of terrorism in Indonesia? What is the strategy for dealing with terrorism in Indonesia? Following the formulation of the problem, this article aims to describe the root causes of the emergence and development and strategy handling terrorism in Indonesia. This article is described using a phenomenological approach with a qualitative descriptive type.

\section{Methodology}

This article uses a type of qualitative research, by doing a series of words and not a series of numbers, the data is obtained in various ways such as observation, interviews, documentation. ${ }^{1}$ To deepen the analysis, the authors used a sociological approach, an approach that seeks to understand the meaning of events and its relation to concepts and theories as well as trying to find and describe the characteristics of problems with objects and events in the research location. ${ }^{2}$ Data collection was carried out through observation, interviews and documentation. There are eight steps that the researcher took in analyzing the data obtained, namely: selecting the domain to be analyzed; identify all contrasts that have been found; prepare a paradigm sheet; identify a two-value contrast dimension; combining closely related contrast dimensions into one; preparing contrast questions for missing features; conduct selected observations to complement the data; setting up a complete paradigm.

${ }^{1}$ Metthew B. Miles, Analisis Data Kualitaif (Jakarta: UI-Press, 1992), p. 15.

${ }^{2}$ Lexy J. Moleong, Metode Penelitian Kualitatif (Bandung: Remaja Rosdakarya, 2001), p. 16. 


\section{Results and Discussion}

\section{The History of Terrorist Development}

Since the beginning, the word terrorism has been used to describe acts of violence by the government or anti-government activities. Terrorism emerged at the end of the 19th century and occurred in almost all parts of the world on the eve of the World WarI. History records in the 1890s acts of terrorism in Armenia against the Turkish government that is ending in a murderous disaster bulk against Armenians during World War I. In that decade, acts of terrorism were identified as part of the left-wing movement based on ideology because they believed that terrorism was the most effective way to carry out a political revolution as well as social with how to kill influential people. ${ }^{3}$

The phenomenon of terrorism has increased from the very beginning decade 70's. Terrorism and terror have developed in the realm of ideology, religious fanaticism, struggle independence and rebellion. Even terrorism is considered by the government as a means and means of enforcing its power. Terrorism styles have developed both from the recruitment side to the characteristics, such as, maximization a very terrible victim. The desire to get coverage in the mass media internationally quickly. No one has ever made a claim against terrorism that was already committed. The terrorism attack can never be predicted because the target is the same as the entire earth's surface area.

For example, in Egypt,was once a hotbed of world terrorism, where the development of the growth of terrorism is proliferating, that is its members comes from young people, especially students and students. A scholar and sociologist Egypt, Saad Edin Ibrahim told that the number terrorism during the previous two decades so somewhat limited Egyptian citizens ignore it. However, it is very surprising that the following period saw a drastic increase in 1992-1993 that shook emotions in Egypt. Terrorism in the 1970s was limited to four regions, while in the first 3 months of the 1990s it spread to more than 14 regions. The number of victims who fell in the first month1993 is the same as the number of victims in 1992. The number of victims in 1992 was four times the number of the previous year. The substantial increase in the number of victims has raised serious fears.

The biggest fact of Islamic terrorism by and large among younger generations who are generally younger than ever. The average age of Islamic terrorists in the 1970s was 28 year, now 21 years. $85 \%$ of fundamentalists in the 1970s were students and university graduates but in recent years of this, $60 \%$ high school students joined their ranks. Likewise, Islamic terrorism has spread from city-big cities to small cities, districts and even villages so that rural areas have become an integral part of the phenomenon of terrorism. Member group terrorism comes from the lower class or those who come from the lower class or close with poverty. They feel that their living standard is being threatened,

3 "Terorisme di Indonesia," in http://likha-ika.blogspot.co.id.makalah-terorisme-di-indonesia. Accessed 2 April 2017. 
even after finishing high school or university, the future is still bleak. The same is true of the Copts. To escape the frustration and bitter fate surrounding them, they join extremist groups that help them earn a living. For them, religion has become a flag of shelter to protest against socio-economic and political pressure because they do not have other means of influencing the government to improve their lot.

The Egyptian government realizes that being confronted by new religious extremism that can threaten the state's existence can even shake the understanding of Islam rahmatan li al-âlamîn. Thus, the Egyptian government began to hunt down terrorists and carry out attacks against terrorists and even arrest fundamentalists. Actions to combat terrorists are also carried out through books and educational materials always campaigning and a war of nerves so that the Egyptians' minds do not like terrorists. Next when the exhibition of international books on Cairo heldin early 1993, a symposium against terrorism was held; al-Azhar restrictions were issued on books scholars well-known ones such as Asmawi and syuhada were revoked, so these books cannot be included in this exhibition.

In October 1992 president Husni Mubarok issued an order, at the level of a law, which allow trial of fundamentalists in military courts even though they are citizens Egypt, on the side allows a short trial which does not entitle a higher court to appeal. From then until late 1993, dozens of death sentences were issued against perpetrating fundamentalist activist violence and more than 25 people have already been executed. Saad Edin Ibrahim wrote in the May 1993 issue of the journal al-Muztama 'al-Madani (civil society) that the 1970's the country was appointed by the liberation process (the October 1973 war) and then the peace process during this period was wholly preoccupied with finding solutions to problems. The economy to treat the illness Egypt, however, fundamentalists work calmly and quietly bulk to control the younger generation's thinking continuously and do the brainwashing.

Terrorism penetrates all secondary school teachers in Cairo and cities province, the teachers who had been recruited later hired as a teacher. In other words, the fundamentalists are in control millions good schoolgirls on level both primary and intermediate throughout Egypt. The unauthorized parties were unaware of the drama going on in front of the nose they, so that this negligence also means allowing the teaching force to swell to support it extremism violence against the state. Ibrahim noted that the core of the fundamentalists is not more than 10 thousand, while the fringe force consists of several hundred thousand, but this is not much compared to what was expected of the fundamentalist teacher army Egypt in the coming year.

These fundamentalist elements are not content to just recruit students, but they also recruited female students, most of whom were still ten years old. These students held massive demonstrations at their school in Qolyub during Ramadan in 1993. They attacked the Copts and burned the church in town. Having noted the socio-economic 
situation and educational problems, now we turn on the challenge faced by the Egyptian government in the field of democracy and civil rights due to fundamentalist terrorism.

\section{The Root of the Problem of the Emergence of Terrorism in Indonesia}

The birth of terrorism results from several factors such as psychological, economic, political, religious, sociology, and many others. It is not easy to explain an act of terrorism based on only one cause, for example, because understanding and psychologically only. But other problems also have to do with things such, as ethnic conflict, religion, ideology, poverty, modernization pressures, political injustice, lack of communication channels for funds, tradition security, the birth of revolutionary groups, the weakness and inability of the government to run the government.

The cause of terrorism is because the existence of tribal egoism, nationalism/separatism (etnicity, nationalism/separatism). Usually acts of terror like this occur in areas that are hit by conflicts between ethnic/ethnic groups or in a nation that wants to set free self, carrying out terror as a means to achieve an important goal or tool in the struggle. The target is clear, namely another ethnicity or nation that is being fought. Bombs set in the crowdor other public places being the most frequent examples. Such acts of terror are random, the victims can be anyone. ${ }^{4}$

Another reason for the occurrence of terror is due to prolonged poverty in a country, it cannot be denied that poverty and inequality have turned out to be social problems that can provoke terrorism. Poverty can be divided into 2 types: natural poverty and structural poverty. Natural poverty is usually said to be "poor by its son." People who live in fertile land will tend to be more prosperous than those who live in barren land. Meanwhile structural poverty is created poverty. This happens when the authorities issue policies that impoverish their people. The second type of poverty has a higher potential for the emergence of terrorism. ${ }^{5}$

According to Khamami Zada, the emergence of radicalism and terrorism are often termed radical Islam suspected with two factors. First, internal factors within the Muslim community itself, this factor occurs because of deviations from religious norms that are half-understood or even misunderstood the text. Life secularists tend to encourage them to understand religious texts. The study of religion is only seen from one textual direction, not seeing from other factors action-the actions they take must refer to Prophet Muhammad SAW.'s behavior literally. The second factor is due to external factors from outside the Muslim community support implementation Islamic law in the joints of life. ${ }^{6}$

${ }^{4}$ Zulkarnain M. Sunusi, Antara Jihad dan Terorisme (Makassar: Pustaka As-Sunnah, 2011), p. $125-126$.

${ }^{5}$ A.C. Manullang, Menguak Tabu Intelijen: Teror, Motif dan Rezim (Jakarta: Panta Rhei: 2001), p. 151.

${ }^{6}$ Khamami Zada, Islam Radikal: Pergulatan Ormas-ormas Islam Garis Keras di Indonesia (Jakarta: Teraju, 2002), p. 7. 
Azyumardi Azra said that, there were several backgrounds for the emergence of internal theory and radicalism Islam because the background, including: First, literal religious understanding, fragments of the verses of the Qur'an and Hadith. Second, misreading of the history of Muslims combined with excessive idealization of Muslims at certain times. This is seen in the views and movements of the salafi, especially inspectrum very radical like the Wahabiyah who appeared to be flattered Arabia in the late 18th century early to 19th century and continues to be in existence today. Third, political, social and economic deprivation that still persists in society, but at the same time, disorientation, socio-cultural dislocation, access to globalization and the like are at the same time additional important factors for the emergence of radical and terror groups. Fourth, the continuation of social political conflicts with intra and nuances between peoplebeing religious during the reformation era, again due to various very complex factors. For example, related with euphoria freedom of society to express its attitude. Further still he continued sociopolitical fragmentation in circles elite political, social, military to the lower ranks that cause horizontal conflicts. Then the inconsistency of law enforcement and its wide spread disorientated and dislocation in Indonesian society. ${ }^{7}$ Fifth, the dissemination of internet content, in addition to print media, terrorism and radicalism groups also utilize social media in cyberspace to disseminate books and information about understandings and values, especially jihad which affects terrorism. ${ }^{8}$

Next, the country that owns the system nondemocracy also pointed out as a place where terrorism flourishes. In a democratic country, all citizens have the opportunity to share all their political views. The democratic climate makes people represent the highest power in state governance. This means that people feel involved in state management. The same thing certainly does not happen in non-democratic countries. Apart from not providing opportunities for public participation, non-democratic rulers are also very likely to carry out repressive actions against their people. This confinement has become a fertile culture for the seeds of terrorism to grow.

Next acts of terror will arise if there is discrimination between ethnic groups or groups in society. This happens when a group is treated differently because of their skin color, religion, or religion. Group those who are humbled will find a way to be heard, recognized, and treated equally with others. An atmosphere like this will again promote a breeding ground for terror. It cannot be denied that the understanding of religion is radical because it can be hard to understand the Qur'an Hadith text. Many of the terrorist incidents that occurred in Indonesia were connected to this cause. Religious radicalism is a unique cause because the underlying motives are sometimes not real unlike poverty

${ }^{7}$ Azyumardi Azra, "Memahami Gejala Fundamentalisme," in Ulumul Qur'an: Jurnal Ilmu dan Kebudayaan, No. 3, Vol. IV, 1993, p. 5.

${ }^{8}$ Rulli Nasrullah, "Politik Siber dan Terorisme Virtual," in Esensia: Jurnal Ilmu-ilmu Ushuluddin, Vol. 13, No. 1, 2012, p. 113. 
or discriminatory treatment that is easily observed. Religious radicalism is grown in part by the world view of its adherents. Assuming that the world is mastered black power and as messengers of God they feel called to free the world from evil hands' grip.

Lately, we are often heard that the stunts are the background acts of terrorism in Indonesia are often linked to Islam. Linking with religion is an attractive, easy way sympathy Muslims because it has become a general truth that religion is a container in creating serenity and the peace of humankind.

Of the majority of cases, religious issues are used as a forum related to faith, religion as a provider ideology, and religion made into as motivation to get high social status and organizational structure of the perpetrators of these crimes. For example course in free interpretation of the verses Qur'an and Hadith with regard to jihad often made into fundamental dogma for the terrorists. Ideology is a powerful weapon for terrorists, something the West does not have. The strength of Islamist terrorists, according to Stepanova, lies in their ideology. For them, the philosophy of life is to maintain faith and jihad, and live a noble life or martyrdom. ${ }^{9}$

\section{Terrorism in Islam}

Islam does not recognize the term terrorism, because the words terrorism and the understanding of terrorism were born from the Western version. Perhaps the notion leading to struggle is literally closer to jihad. In epistemology, jihad comes from the Arabic al-juhdu or al-jahdu which is the masdar form of the word jahada. So, al-juhdu or al-jahdu is out pouring ability and power to challenging something else. So in sharia, this word is defined as fighting people hat prescribed to be fought from among the infidels and others. ${ }^{10}$

However, there are many arguments from the verses of the Qur'an and hadith that contain the sentence jihad and often interpreted with a harsh and cruel meaning so that acts of violence arise in upholding religion, for example, in Surat al-Taubah verse 111: "Indeed, Allah has bought from the believers themselves and their property by giving them paradise. They fight in the way of Allah; then they either kill or get killed. (It has become) the true promise of Allah in the Torah, the Bible and the Qur'an. and who keeps his promises (other than) than Allah? So be happy with the buying and selling you have done, which is a great victory." 11 Likewise in Surat al-Taubah verse 123, Allah reminds people as follows: "O you who believe, fight against the disbelievers around you, and let them meet violence from you, and know that Allah is with those who are righteous." 12

9 Sukendar, "Akar Terorime dalam Islam?," in Theologia, Vol. 22, No. 2, 2012, p. 422.

${ }^{10}$ Ardiansyah, "Perkembangan Makna Kata Irhab (Teroris) dan Jihad (Jihad) Dalam Bahasa Arab," in At-Turats: Jurnal Pemikiran Pendidikan Islam, Vol. 9, No. 1, 2015, p. 65.

${ }^{11}$ Q.S. Al-Taubah/9: 111.

${ }^{12}$ Q.S. Al-Taubah/9: 123. 
In perspective Hadith, as narrated Anas r.a., actually the Prophet SAW. said: "fight the polytheists with your wealth, self and your tongue." There are many scholars' thoughts in providing an understanding of jihad with a strong understanding like Ibn Rushd's view, "Everyone who burdens himself because of Allah, then he has jihad in it. It's just that, if the jihad fî sabîlillâh stated, then there is no other purpose except to fight the disbelievers with the sword, so that they will enter Islam or give jizyah obediently and they submit."

The above texts contain the sentence jihad, that is understood it is as if the text contains violence because it invites war, but in fact it must be understood in a context so that the conditions at that time lead to problem solving. These arguments are actually not the legal basis and foundation to justify their acts of terror because one has to know who object/the real enemy that must be fought, how are the procedures for the implementation and the rules, considering that the Prophet SAW. also applied a rule in the procedures for fighting for mujahidin at that time. For example it is forbidden to kill children, women, the elderly, even people Christian who are worshiping in his church as well prohibition of tampering with the place worship.

Even so, it does not mean that terrorism is not a crime, especially if it is related to the issue of its macro impact even though it uses the category "jihad." If innocent human beings become victims and the public interest falls apart and the state is hit by national disharmony, then the category of "jihad" and any religious reasons that justify this outrage should be questioned.

According to Ma'ruf Amin, according to the MUI fatwa, there is a very principle difference between carrying out terror and waging jihad. Jihad has targets and areas for war activities the culprit is called mujahid and if he dies in battle, it will be called martyred. Meanwhile, terror is a disturbing activity peace something territory what was originally safe, serene and peaceful turned into a scary atmosphere. People are afraid because anyone can easily become a terror target. Many innocent people were victims. Not to mention that the damage is so large that it requires funds to rehabilitate it. There are also other socio-economic impacts experienced by countries that are victims of acts of terror. Because this terror made the situation chaotic, we cannot say the culprit martyred. ${ }^{13}$

The above doctrine is one of the thousands of doctrines instilled in terrorists, where they do not know the true purpose and purpose of values essential jihad, so they only think about the lure of reprisals and rewards for their acts of terror.

Because of that the Prophet had reminded long ago that the mujahidin who were rewarded were those whose intentions were sincere lillâhi ta'âla, not mixed with wanting to be seen and known. They too never thought what gift God would give him, because of the mujahidin really struggled sincerely to enforce Allah's words in his heart.

${ }^{13}$ Ilyas Supena, "Mujahid Versus Teroris," in Walisongo: Jurnal Penelitian Sosial Keagamaan, Vol. 20, No. 1, 2012, p. 178. 
From Abû Mûsa ra., he said, "Rasulullah SAW. was asked about a person who fought because of courage, because of fanaticism and fought because he wanted to be known." Which one is said to fight fi sabîllillâh, O Messenger of Allah?" Rasulullah SAW. replied "Whoever fought so that Allah's sentence was upright and high, then he was declared to have fought $f i$ sabîllillâh."

From Abû Hurairah ra. He said, "There was someone who asked Rasulullah SAW. He asked, O Messenger of Allah, there is a person fight fi jihad sabillillâh but the aim is to gain world standing. So the Prophet replied, He will not be rewarded (repeating the word three times) Lâ ajru know!" (H.R. Abû Daud).

This leads to a question if terrorism justifies violence in achieving its goals, then how with jihad, what does it have in common with terrorism? This is a striking but straightforward question. If the jihad did come from ideology diversity, it would undoubtedly have positive consequences for its adherents and people because religion must have standardization or a separate norm in implementing the jihad following its purpose become rahmat li alâlamîn. So, jihad is completely different from acts of terrorism which always justify any means to achieve its goals.

If they justify violence by packaging jihad as a label without going into meaning essential From the meaning of jihad itself to the loss of innocent lives being victims, the validity of this jihad should be questioned again. The concept that is practiced by the label of jihad is deemed inaccurate, so that this understanding needs to be prevented, avoided and combated.

\section{The Character and Target of Terrorism}

A terrorist character analyzed from practical experience in handling action terrorism conducted by the United Nations, among others, are as follows: First, terrorists generally have strong organizations and dependable, have discipline high, are militant in nature, and have an organizational structure consisting of small and commando orders done through indoctrination - terrorist built through years of strenuous training before executing the action. Grow and development are evenly distributed around the world and the tendency to develop in majority areas Muslim population. Second, terrorists think that it is very difficult to obtain change and get the desired results through a peaceful process but must go through a revolutionary movement. Therefore, character they continue to do action-continuous action, militant, never give up and dare to take any risk as long as their goals are achieved. Their leaders oblige their members to recruit successive cadres who are ready to be invited to continue the struggle. Third, usually, terrorists choose actions to achieve political goals they want achieved with criminal ways and disregarding 
religious norms and applicable laws because they think this is a time of war. Fourth, choose targets with high psychological effects to create fear and gain wide publicity. ${ }^{14}$

In the opinion of the author, through its character, terrorists in achieving their vision and mission have strategic goals, including: First, shows the weakness of the tools of power (government apparatus). Second, it is raising conflict and radicalism in society or specific segments of society. Third, humiliating government officials and provoking them to act repressive then discredit the government and generates public sympathy for terrorist goals. Fourth, using social media a means of disseminating propaganda and terrorist political goals. Fifth, the physical targets of the buildings include Military installations, buildings object vital such as energy generators, communication installations, industrial estates, tourism and transportation facilities. The sixth is related topersonnel government officials, diplomats, business people and personnel political opponents. Thus the targets of terrorist acts are generally against humans as well object others must be guarded with system who is better than system terrorist. The goal to highlight weaknesses system governance designed to generate positive or sympathetic public reactions to terrorists.

\section{Development of Terrorism in Indonesia}

Terrorism in Indonesia is carried out by the militant group Jemaah Islamiyah which is linked to al-Qaeda or other militant groups that use similar ideologies to them. Since 2002, several "Western targets" have been attacked. The victims who fell were Western tourists as well as Indonesian residents. Terrorism in Indonesia began in 2000 with the Jakarta Stock Exchange Bombing, followed by four other major attacks, the most deadly of which was the 2002 Bali Bombing. ${ }^{15}$

The battle then reopened the history of the struggle of the theocratic state and the secular state (democracy). World history records the defeats of several world religions such as Christianity, Islam, Hinduism, Buddhism in the struggle for control over the state which is the regulator of society. Post-rule (regional-global) Ottoman Turks, then the Islamic world returned to the country's smaller territories. There have been several models in Middle Eastern countries, such as the collaboration of family dynasties with Wahhabi teachings (Saudi Arabia), the development of secularism, and the creation of resistance cells for an Islamic state's struggle in various countries.

After the victory of the principles of Indonesian nationalism, some Islamic groups were very disappointed. Even the elements of the Islamic military fighters (Islamic Army) then drafted the concept of Darul Islam and the Islamic State of Indonesia (DI/NII) in

\footnotetext{
${ }^{14}$ Biyanto, "Mengurai Benang Kusut Terorisme, Memahami Penyebab, Karakter dan Solusi," in Al-Buhust, Vol. 9, No. 1, 2013, p. 159.

15 "Teroris di Indonesia: Dulu dan Sekarang ..." in https://nasional.kompas.com, August 22, 2016.
} 
West Java in 1949 with S.M. Kartosuwirjo and in Aceh in 1953 under the leadership of Daud Beureuh. Besides elements of the Islamic Army resistance to the formation of the Unitary State of the Republic of Indonesia, also developed elements of the "jihad" pesantren (around 70 in number) and elements supporting Islamic law from the Masyumi party which was destroyed by the Soekarno government. In the New Order era since 1965, the Indonesian government with a violent approach to militarism, carried out a policy of destroying the latent dangers of the radical left (communism) and the radical right (Islam). This has sharpened the resentment of these groups of Indonesian people who are in the right and left radical categories so that all of them enter into increasingly violent nursery cells. Pesantren Ngruki (1972) built by Abu Bakar Baasyir is only one of the other pesantren that also teaches jihad, but this cannot be generalized into the world of terrorism.

The research states that terrorist organizations show that suicide bombing behavior is not taught in Islamic boarding schools, but occurs in resistance movements against governments that are considered infidels. This in modern history refers to the pattern of strategies applied by groups Hezbollah in Lebanon. This was considered successful in frightening opponents but was later reduced by the Western world (the US and its allies) as international terrorism, so that the image of the heroism of the suicide bombing Hezbollah turned into Terrorist Coward Action.

Indonesia has historically known suicide bombings, for example in Aceh when they fought the Dutch as Aceh Moord. All of us of course would really respect the most heroic action in the history of Indonesian independence in 1945 which was carried out by Muhammad Toha in South Bandung by blowing himself up in a gunpowder warehouse in order to weaken the power of the Dutch, which became known as "Bandung Lautan Api." That means, we will never call Muhammad Toha's actions cowardly, right? Otherwise it will pay homage and prayers, and we acknowledge the heroism of Muhammad Toha.

Likewise, what happened in the modern Indonesian terrorism movement, this group considers its actions to be noble actions, which is contrary to our general view which sees them as contemptible. We analysis of course, terror incidents in Indonesia occurred due to several important reasons including: First, the history of our nation's struggle that is not afraid of dying is still within us, so that if there is a part of the Indonesian nation that has a character of resistance, it is not afraid to die. This quality was not shared by neighboring countries which obtained independence easily free of charge from their kind colonial powers. Second, the majority of Indonesian Peaceful Muslims since the 11th century $\mathrm{AD}$ have a silent character and only react when an event disturbs peace, so it takes a long time to raise awareness of the existence of a handful of Muslims who use violent means to achieve their goals. Third, the majority of Indonesian Muslims carry a subconscious history of strong suspicion against Western intervention as happened in the Nusantara war in Indonesia and the Crusades in the world, so it will be difficult to believe if Muslims have the heart to hurt others, let alone acts of terror. Fourth, that Indonesia is land that very 
fertile for the birth of the radical right (the government's version) because of the repression policies that were wrongly targeted by the New Order government. In the reform era there were improvements where dialogue has taken place from various elements of the nation so that a more just situation can be achieved in the future.

\section{Strategy for Handling Terrorism}

Effort government in repeating acts of terror in the Unitary State of the Republic of Indonesia needs a precise strategy and strategies for dealing with terrorism that can be carried out. First, strengthening the role of ulama. Ulama are the scientific lanterns of people who experience darkness of understanding fanaticism only a fraction of the religion he understood. Understanding religion based on individual and group logic without scholars' participation will have a negative impact on science and understanding of itjihad. In this regard, the role of scholars is expected to provide understanding to society in space time in various recitation activities and recitation assemblies that are carried out periodically or in small or large groups. Existence of ulama in Indonesia are believed to be able to take a good religious approach with terrorists in Indonesia other than those who have charismatic. They are also the people closest to the community in a socio-religious context. Through recitation and recitation assemblies carried out are expected to provide a deep understanding of Islam so that Islam as a religion rahmatan li al-'âlamîn becomes not only as a principle of life, but integrated in various field social life society.

Ulama can become facilitators and mediators of terror actors who are members of terrorism rooted in Indonesia in particular and in parts of the world in general. Goods times combat by doing arrest not being the primary solution for terrorism in parts of the world, but mediation and facilitators to return understanding and panic terrorists need to be tried and implemented. This approach is expected to be carried out by scholars who have firm religious knowledge and experience problem solving social and individuals who have joined terrorist groups who are considered wrong in acting and understanding the text.

We wish the ulama who remained at mercy to people, provide solid guidance of faith, develop and create peace spiritual. We believe that educational institutions and training they have followed; there are no narratives that lead to the emergence of radicalism or terrorism. On the contrary, they are still very strong in protecting the purity of Islamic teachings from the touch of radical thoughts and actions spoil like terrorism. ${ }^{16}$

The second is strengthening the role of Islamic religious higher education. Apart from scholars, institutions that can provide view higher levels of terrorism groups that

${ }^{16}$ M. Hasbi Amiruddin, "Isu Terorisme dan Respons Aktivis Muda Aceh," in Walisongo: Jurnal Penelitian Sosial Keagamaan, Vol. 22, No. 1, 2014, p. 33. 
have penetrated certain individuals and social groups are tertiary institutions. As a tertiary institution that provides a lot of scientific discourses or discourses for students, it is hoped that they will be more independent in various matters, especially right field basic human beings so that panic in certain areas is not hastily misunderstood. Deep discussion discourse activity student affairs can lead to negative if discussion of religious studies as one of the topics for student misunderstanding to act as anarchists and terrorists. For this reason, higher education institutions are expected to provide a curriculum in course material with impart Islamic values that can be absorbed and understood well for students. This expectation is fundamental because college graduates will become point of view measuring and extend their knowledge to the community. Of course, the community will fully accept if those who convey this knowledge are intellectuals who have studied at various universities. If what is conveyed is the doctrine of goodness, then the people will immediately accept it, on the other hand, if what is conveyed is the doctrine of anarchism and terrorism, then it will naturally become ingrained and ingrained for the community itself.

Higher education institutions are expected to be a bridge for student scholarship so that they do not misunderstand literature problematic social community bridging radicalism thought, fundamentalism, pluralism mature ones this becomes a social philosophy partially misunderstood great society. Public trust for higher education should be built as an independent scientific institution, not as an institution that can produce scientists on the flow of violence and terror. For that, universities can reflect on student activities and other lecturers. The studies that can steer to anarchism and terrorism, the explosion is minimized and directed to activities that contain Islamic values, for example, mutual respect, tolerance, honesty, each other understand, love, help, and others. Activities of academics facilitated in the public sphere to social assistance, help health, economic assistance, scientific assistance, and personnel assistance so that higher education institutions have a positive role for the nation and homeland. ${ }^{17}$

Such condition needs proactive response from all levels of society. Significantly higher education as a center of excellence must dore positioning in the context of the external environment through internal restructuring efforts that are well-planned, wellactuated, and well-evaluated/controlled in a spirit of continuous updating. Unsold builds a strategy through the hidden curriculum by playing LP3M Unsoed Purwokerto through the General Compulsory Course (MKWU), which is considered very strategic for educating anti-terrorism and radicalism students. ${ }^{18}$

Third, strengthening the role of government. The facts about acts of terrorism and statements from various sources regarding the development of terrorism in Indonesia

${ }^{17}$ Ulul Huda, "Strategi Penanggulangan Radikalisme di Perguruan Tinggi Kabupaten Bayumas," in Jurnal An-Nizam, Vol. 8, No. 1 2018, p. 33.

${ }^{18}$ Ahmad Jayyadi, "Deradikalisasi Agama Dalam Strategi Penanggulangan Radikalisme dan Terorisme di Universitas Jenderal Soedirman dan IAIN Perwokerto," in An-Nidzam: Jurnal Manajemen Pendidikan dan Studi Islam, Vol. 5, No. 2, 2018, p. 35. 
explain that Indonesia is categorized as prone to acts of terrorism. Extreme bigotry towards religion, the wrong doctrine of the messages that are infant religion and low education becomes factor it is essential to be involved in various acts of terrorism. Thus, through related parties, the government needs to make strategic policies to tackle these acts of terrorism. Such action can done in various ways, including:

\section{a. Strengthening State Defense Institutions (TNI and POLRI)}

Institutional strengthening defense country that has carried out like the military sector carried out underground operations, with pressure to destroy terrorist groups. Everyone planning and assisting terrorist operations must understand that he will be hunted down and punished. Their operations will be disrupted, and finances will be drained, hideouts will continue to be raided. If this works, there will be no more problems in the military sector. The operation will be more effective if the team combines Densus 88/Anti-terror from the police and TNI anti-terror units. Obstacles to the provisions of laws and SOPs should be overcome with long-term thinking because the threat of terror clearly disturbs the development and credibility of Indonesia's security conditions in the eyes of other countries. Everything the government manages to collapse in the blink of an eye with a terror attack. This is the essential value that we must realize together.

\section{b. Strengthening the Framework of the Republic of Indonesia}

As a unitary state, namely The Unitary State of the Republic of Indonesia (NKRI) under the auspices of Pancasila and the 45 Constitution, a country that has swallowed many pills bitter Dutch and Japanese colonialism and various other armed group rebellions. Indonesia is a country that has a million experiences in dealing with rebellions, both internal and external actors. The nation's bitter pill was extended by the birth of a terrorist groupon behalf of religions and other social groups. As a country that has basic guidelines for the unity of Pancasila and various constitutions of the nation, it should fully adhere to state regulations. For example, policies and government established body security in terrorism are considered good, Densus 88 is expected to be more observant and professional in identifying and arresting those suspected of being terrorists. So that public trust in Unitary State of the Republic of Indonesia is not tarnished with wrong arrests, wrong aiming and other mistakes. Protect sovereignty the territory of the Republic of Indonesia and all of its contents from terrorist movements and activities as well as preventing grip, threats, pressure from other countries under the pretext of fighting terrorism and radicalism. ${ }^{19}$

${ }^{19}$ Folman P. Ambarita, "Penanggulangan Tidak Pidana Terorisme," in Binamulia Hukum, Vol. 7, No. 2, 2018, p. 146. 
Strengthening framework Unitary State of the Republic Indonesia is in the hands of the national defense sector and the role and responsibility of the community come along and defend their homeland. Participation of civil society here emphasizes reporting to parties in authority when an understanding of radicalism and acts of terrorism emerges, whether small or large. For example, suppose a new understanding of religion emerges in society that causes unrest. In that case, the first thing that can be done is to understand radicalism not develop to cause acts of terrorism that smells of violence and conflict is to report or consult religious leaders and figurethe people in the neighborhood.

Thus, the figures should take initial preventive measures, such as holding discussions about new understandings emerging in the community with the parties concerned. Finally, maintaining unity and integrity can also be done as an effort to prevent the understanding of radicalism and acts of terrorism in the community more so at the state level. As we realize that in a society there must be diversity or plurality, especially in a country which is a combination of various societies. Therefore, maintaining unity and integrity in the presence of diversity is very necessary to prevent problems of radicalism and terrorism. One thing that can be done in the case of Indonesia is to understand and run the values contained in Pancasila, as the motto stated there is Unity in Diversity.

\section{c. Minimizing Social Inequality}

The social inequality that occurs can also trigger an understanding of radicalism and action terrorism. Second order this does not happen, then social in equality must be minimized. If the level of understanding of radicalism and acts of terrorism does not want to occur in a country, including Indonesia, then the gap between the government and the people must be minimized. The trick is that the government must able to accommodate desire and community needs as well as the media that act as intermediaries with the people as well as taking real action directly against the people. Likewise with the people, they should always provide support and trust to the government that the government will be able to carry out its duties properly as protector of the people and in control of the state government.

\section{d. Reducing Human Rights Violations}

Efforts to prevent and anticipate the spread of terrorism must not stop. This is because the understanding and propaganda of terrorism has been embedded in the head, heart and attitude of sympathizers and followers of this organization. If deradicalization hasn't been done, don't expect them to realize. That is, effort counter radicalism will continue. Like plants, we must not let their land become fertile. We believes that Islam is actually a religion that breathes love and peace. The problem is that terrorism has made Islam the scapegoat for many movements and actions carried out by this group. In fact, religion is 
a means of creating benefit for humans on earth. Benefit these include universal values such as justice, compassion, unity, tolerance, peace and so on. Actually, religion as a message of peace is full of teachings that defend and guarantee human values. In this case, Islam guarantees and protects human rights. In fact, Islam also guarantees freedom of religion. Indeed, terrorism can arise because of this error in interpreting religious motivations. Religious sentiment is often one of the causes of terrorism. However, the latest rampant acts of terrorism are not motivated by religion. Violence appears to lead to group reactions that are frustrated and disappointed by global injustice and actions of Western countries.

\section{e. Formulating laws}

As a country that has a strong constitutional order, handling radicalism and terrorism should formulated in strong and firm laws. The laws are formulated based on sociology and societal anthropology big, so that it can become a good legal umbrella relevant to the context of Indonesia. In addition, after the formulation of the law exists, handling against terrorists must have a structured operational standard, from identification, arrests and legal provisions for the perpetrators. So that the policies and implementation of handling terrorists have a deterrent effect and eventually return to their knees Unitary State of the Republic Indonesia. Terrorism cannot be called an ordinary crime, terrorism is an extraordinary crime and is also categorized as a crime against humanity or crime against humanity. Therefore, the formulation of a special minimum criminal threat is needed in optimizing the prevention and eradication of criminal acts that are serious threats and give a deterrent effect to the perpetrators. ${ }^{20}$

\section{f. Conducting Cooperation between Countries}

Cooperation can be categorized into thetwo forms namely strategic plan and action. Cooperation in form strategic plan for example, such as the MoU, agreements, and so on. Meanwhile, cooperation in form action more on joint operations establishes agencies or institutions and organizes forums or meetings. Strategic plan what it does is agree on Memorandum of Understanding (MoU) and other cooperation concepts. While in form action, formed combined operations the Bali Bombing investigation. Until 2004, JCLEC was established in Indonesia as a center for law enforcement cooperation between the Indonesian-Australian police, POLRI and the AFP. ${ }^{21}$

${ }^{20}$ Randy Pradityo, "Kebijakan Hukum Pidana Dalam Upaya Penanggulangan Tindak Pidana Pendanaan Terorisme," in Jurnal Rechtsvinding, Vol. 5, No. 1, 2016, p. 30.

${ }^{21}$ Shara Yosevina Simanjuntak, et al. "Analisis Kerjasama Bilateral Indonesia Dengan Australia Dalam Penanggulangan Terorisme Sebagai Kejahatan Transnasional Terorganisir (2002-2015)," in Journal International Relations, Vol. 2, No. 3, 2016, p. 125. 


\section{Conclusion}

Several things are root causes the background the birth of terrorism in Indonesia, including: understanding religious literal, wrong reading of the history of Muslims combined with idealization exaggerated against Muslims at a certain time. Political, social and economic deprivation still persists in society, but at the same time, disorientation, sociocultural dislocation, and access to globalization. Besides, it still continues uphoria freedom of society to express its attitude. Next still continued socio-political fragmentation in circles elite political, social, military to the lower ranks that cause horizontal conflicts. Then no consistency law enforcement and its extent disorientation and dislocation in Indonesian society.

Strategic approaches that can be taken in dealing with terrorism include strengthening the role of ulama in society, strengthening the role of higher education institutions as higher education institutions that can change the paradigm, think students and strengthening the government's role in tackling existing acts of terrorism. The role of the government in efforts to tackle existing terrorism requires other strategic approaches that can be taken such as strengthening the national defense institution (TNI-POLRI), strengthening the framework Unitary State of the Republic Indonesia, minimize social inequality, reduce offense right basic humans, and formulate laws following the sociology and anthropology of the local community.

\section{References}

Ambarita, Folman P. "Penanggulangan Tidak Pidana Terorisme," in Binamulia Hukum, Vol. 7, No. 2, 2018.

Amiruddin, M. Hasbi. "Isu Terorisme dan Respons Aktivis Muda Aceh," in Walisongo: Jurnal Penelitian Sosial Keagamaan, Vol. 22, No. 1, 2014.

Ardiansyah. "Perkembangan Makna Kata Irhab (Teroris) dan Jihad (Jihad) Dalam Bahasa Arab," in At-Turats: Jurnal Pemikiran Pendidikan Islam, Vol. 9, No. 1, 2015.

Azra, Azyumardi. "Memahami Gejala Fundamentalisme," in Ulumul Qur'an: Jurnal Ilmu dan Kebudayaan, No. 3, Vol. IV, 1993.

Biyanto. "Mengurai Benang Kusut Terorisme, Memahami Penyebab, Karakter dan Solusi," in Al-Buhust, Vol. 9, No. 1, 2013.

Huda, Ulul. "Strategi Penanggulangan Radikalisme di Perguruan Tinggi Kabupaten Bayumas," in Jurnal An-Nizam, Vol. 8, No. 12018.

Jayyadi, Ahmad. "Deradikalisasi Agama Dalam Strategi Penanggulangan Radikalisme dan Terorisme di Universitas Jenderal Soedirman dan IAIN Perwokerto," in AnNidzam: Jurnal Manajemen Pendidikan dan Studi Islam, Vol. 5, No. 2, 2018.

Manullang, A.C. Menguak Tabu Intelijen: Teror, Motif dan Rezim. Jakarta: Pantarhei, 2001. Miles, Metthew B. Analisis Data Kualitatif. Jakarta: UI-Press, 1992. 
Moleong, Lexy J. Metode Penelitian Kualitatif. Bandung: Remaja Rosdakarya, 2001.

Nasrullah, Rulli. "Politik Siber dan Terorisme Virtual," in Esensia: Jurnal Ilmu-ilmu Ushuluddin, Vol. 13, No. 1, 2012.

Pradityo, Randy. "Kebijakan Hukum Pidana Dalam Upaya Penanggulangan Tindak Pidana Pendanaan Terorisme," in Jurnal Rechtsvinding, Vol. 5, No. 1, 2016.

Setiawan, Muhammad Arif. "Kriminalisasi Terorisme di Indonesia Dalam Era Globalisasi," in Jurnal Hukum Ius Quia Iustum, Vol. 9, No. 21, 2002.

Simanjuntak, Shara Yosevina, et al. "Analisis Kerjasama Bilateral Indonesia Dengan Australia Dalam Penanggulangan Terorisme sebagai Kejahatan Transnasional Terorganisir (2002-2015)," in Journal International Relations, Vol. 2, No. 3, 2016.

Sukendar. "Akar Terorime dalam Islam?," in Theologia, Vol. 22, No. 2, 2012.

Sunusi, Zulkarnain M. Antara Jihad dan Terorisme. Makassar: Pustaka As-Sunnah, 2011.

Supena, Ilyas. "Mujahid Versus Teroris," in Walisongo: Jurnal Penelitian Sosial Keagamaan, Vol. 20, No. 1, 2012.

Zada, Khamami. Islam Radikal, Pergulatan Ormas-ormas Islam Garis Keras di Indonesia. Jakarta: Teraju, 2002.

"Teroris di Indonesia: Dulu dan Sekarang..." in https://nasional.kompas.com, August $22,2016$. 